\title{
RECIPROCAL TEACHING LEARNING: IS IT EFFECTIVE TO IMPROVE STUDENTS' HIGHER ORDER THINKING SKILLS AND SCIENTIFIC PROCESS SKILLS?
}

\author{
Rofiatul Hidayah $^{1}$, Sri Latifah ${ }^{2 *}$, Happy Komikesari ${ }^{3}$, Irwan Yusuf ${ }^{4}$ \\ ${ }^{1}$ SMP Insan Mandiri, Lampung, Indonesia \\ ${ }^{2,3}$ Department of Physics Education, Universitas Islam Negeri Raden Intan Lampung, Indonesia \\ ${ }^{4}$ SMA N 5 Yogyakarta \\ *Corresponding author: srilatifah@radenintan.ac.id
}

\begin{tabular}{|c|c|}
\hline Article Info & ABSTRACT \\
\hline Article history: & \multirow{8}{*}{$\begin{array}{l}\text { This study aimed to measure the effectiveness of using the } \\
\text { reciprocal teaching learning model on the higher order thinking } \\
\text { skills and science process skills of students. The research method } \\
\text { used is a Quasi Experiment. Based on the results of the research } \\
\text { calculated by the independent sample t-test from the post-test } \\
\text { results of the control class of } 66.97 \text { and the experimental class of } \\
77.71 \text {, it was obtained t tount }>\text { table ( } 10.167>1.996) \text { and the } \\
\text { percentage of observation results from the control class average of } \\
73 \text { and the mean The experimental class average is } 76 \text {, so that the } \\
\text { tcount value is greater than the } t_{\text {table }}((3.656>1.996) \text {. Then the } \\
\text { effectiveness of the reciprocal teaching model is known through the } \\
\text { effect size test and the value of } d=0.5 \text { is obtained. Based on these } \\
\text { results, it can be concluded that the reciprocal model This teaching } \\
\text { is effective in improving higher order thinking skills and science } \\
\text { process skills. }\end{array}$} \\
\hline Received: October 30, 2020 & \\
\hline & \\
\hline Published: March 31, 2021 & \\
\hline Keywords: & \\
\hline & \\
\hline & \\
\hline Science process skills & \\
\hline
\end{tabular}

\begin{tabular}{|c|c|}
\hline \multicolumn{2}{|c|}{$\begin{array}{c}\text { RECIPROCAL TEACHING LEARNING: APAKAH EFEKTIF } \\
\text { UNTUK MENINGKATKAN KEMAMPUAN BERPIKIR TINGKAT } \\
\text { TINGGI DAN KETERAMPILAN PROSES SAINS SISWA? }\end{array}$} \\
\hline & ABSTRAK \\
\hline Kata Kunci: & Penelitian ini bertujuan untuk mengukur efektivitas model \\
\hline $\begin{array}{l}\text { HOTS } \\
\text { Reciprocal teaching } \\
\text { Keterampilan proses sains }\end{array}$ & $\begin{array}{l}\text { Reciprocal Teaching Learning terhadap kemampuan berpikir } \\
\text { tingkat tinggi dan keterampilan proses sains peserta didik. Metode } \\
\text { penelitian yang digunakan adalah Quasi Eksperimen. Berdasarkan } \\
\text { hasil penelitian yang dihitung dengan uji independent sampel t test } \\
\text { dari hasil postetest kelas } 69 \text { ontrol sebesar } 66,97 \text { dan kelas } \\
\text { eksperimen sebesar } 77,71 \text { memperoleh thitung }>\text { tabel }(10,167> \\
1,996) \text { dan presentase lembar observasi rata-rata kelas } 69 \text { ontrol } \\
\text { sebesar } 73 \text { dan kelas eksperimen sebesar } 76 \text { memperoleh nilai thitung } \\
\text { yang lebih besar dari tabel }((3,656>1,996) \text {. Kemudian keefektifan } \\
\text { model Reciprocal Teaching diketahui dengan uji effect size yaitu } \\
\text { memperoleh nilai d }=0,5 \text {. Berdasarkan hasil ini, dapat disimpulkan } \\
\text { bahwa model Reciprocal Teaching ini efektif dalam meningkatkan } \\
\text { kemampuan berpikir tingkat tinggi dan keterampilan proses sains. }\end{array}$ \\
\hline
\end{tabular}




\section{INTRODUCTION}

The process of developing the abilities of an individual takes a long time, in maximizing this process, learning is needed. Learning is the most important key in any educational endeavor, because without learning there is no education [1]. In addition, learning is also an activity that cannot be separated from human life. The learning process is, in principle, the development of the overall personality attitude, especially regarding the activities and creativity of students through interaction and learning experiences.

To achieve ideal learning outcomes, the ability of educators, especially teachers, in guiding the learning of their students is highly demanded. If teachers are ready and have high teaching abilities, the hope of creating quality human resources will certainly be achieved. The teacher is the spearhead of learning, therefore the teacher must have ideal learning characteristics [2]-[7].

The teaching and learning process can be said to be going well if the process can generate effective learning activities, and learning objectives can be achieved properly, so that the targeted learning outcomes can be achieved [1], [5], [8], [9]. Teachers are required to play a dual role, as teacher itself and as a mentor in schools. Learning is a process that emphasizes educating students [3], [10]-[12]. However, in practice, it tends to be monotonous and conventional by focusing teachers as a source of knowledge (teacher centered) [13]-[16].

Problems in conventional learning can be overcome by implementing innovative learning [17]-[20]. Innovative learning is learning that is able to attract students' attention through student involvement in the learning process [18], [19], [21]-[23]. However, active and fun learning is not enough if the learning process is ineffective, that is, it does not encourage students to master concepts. In a lesson there are a number of goals that must be achieved. If learning is only active and fun but not effective, then learning is just like playing around.

One of the innovative learning models is the Reciprocal Teaching learning model. Reciprocal Teaching model requires student activeness to acquire knowledge and understanding independently [24]-[26]. This model is based on the principle of constructivism and the skills process in science process skills. This model understands how children think, communicate, discuss, and learn independently [27], [28]. Through the application of the reciprocal teaching model, students are expected to be able to learn effectively and meaningfully by building their own understanding, so that students are willing to apply higher-order thinking understanding and improve their science process skills.

Physics is one of the subjects taught in stages, from concrete to abstract and continuously. The objective of the Physics subject is to develop experiences for formulating problems, proposing and testing hypotheses through experiments, designing and assembling experimental instruments, collecting, processing, and interpreting data, and communicating the results of experiments orally and in writing. In learning physics, students are expected to develop their thinking skills independently. Students are required not only to have low-level abilities but also higher-order thinking skills. Higher-order thinking skills are a thought process that is not just memorizing and relaying known information. Higher order thinking skills are also the ability to connect, manipulate, and change existing knowledge and experience to think critically and creatively to make decisions and solve problems in new situations that cannot be separated from everyday life. 
The results of the pre-research at SMAN 1 Kalirejo Central Lampung found several problems in the teaching and learning process, including when the teacher explained, there were some students who did not pay attention, were still chatting with their classmates, many students were sleepy during the learning process, and learning conditions were still dominated by teachers, so that physics learning only in one direction. If the class situation is going on this way, then the topic presented can only be accepted by a few students.

Based on the data obtained at the time of the pre-research, it was known that the condition of class $\mathrm{X}$ students at SMAN 1 Kalirejo, from the daily test scores of class $\mathrm{X}$ MIA 3 there were 24 students who did not pass, and in class X MIA 1 there were 18 students who did not complete, so the total was more of 50 percent of students have not reached the graduation standard, this means that there are still learning problems in both classes. Researchers tried to apply the reciprocal teaching learning model in order to improve higher-order thinking skills and science process skills in class X MIA 3 as an experimental class and class X MIA 1 as a control class using direct learning.

This research was conducted to determine the effectiveness of the reciprocal teaching model on higher order thinking skills and science process skills of students at SMAN 1 Kalirejo, Central Lampung.

\section{METHOD}

This study aims to determine the effectiveness of the reciprocal teaching learning model in improving higher-order thinking skills and science process skills. This Quasy Experiment study uses the Non-Equivalent Control Group design. This research was conducted at SMAN 1 Kalirejo Central Lampung with a population of 98 students with a sample of class X MIA 1 as the experiment class and class X MIA 3 as the control class..

Before the instrument is used in the study, it is first tested for validity, reliability, difference power and level of difficulty. The data analysis technique used the SPSS 18.00 statistical application, those are normality, homogeneity, and hypothesis tests. The effectiveness of the reciprocal teaching model is determined by the effect size test. The effect size is a measure of the magnitude of the effect of a variable on other variables [4]. Effect Size can be calculated by:

$$
d=\frac{m_{A}-m_{B}}{\left[\left(s d_{A}^{2}+s d_{B}^{2}\right) / 2\right]^{1 / 2}}
$$

With:

$$
\begin{array}{ll}
\mathrm{d} & =\text { effect size } \\
\mathrm{m}_{\mathrm{A}} & =\text { the mean value of the experimental class } \\
\mathrm{m}_{\mathrm{B}} & =\text { the mean value of the control class } \\
\mathrm{sd}_{\mathrm{A}} & =\text { the standard deviation of the experimental class } \\
\mathrm{sd}_{\mathrm{B}} & =\text { the standard deviation of the control class }
\end{array}
$$

The criteria for the effect size can be seen in Table 1.

Table 1. Effect Size Criteria

\begin{tabular}{cc}
\hline Effect Size & Category \\
\hline $\mathrm{d}<0,2$ & Small \\
$0,2<\mathrm{d}<0,8$ & Moderate \\
$\mathrm{d}>0,8$ & High \\
\hline
\end{tabular}

Science process skills are determined by a Likert scale score.

$$
\% \text { Science Process Skill }=\frac{\text { Score obtained }}{\text { maximum score }} \times 100
$$


The data obtained is then interpreted into the value criteria as shown in Table 2.

Table 2. SPS Score Interpretation Criteria

\begin{tabular}{cc}
\hline Percentage & Information \\
\hline $81-100$ & Very good \\
$61-80$ & Good \\
$41-60$ & Moderate \\
$21-40$ & Poor \\
$0-20$ & Very poor \\
\hline
\end{tabular}

The entire research procedure can be seen in Figure 1.

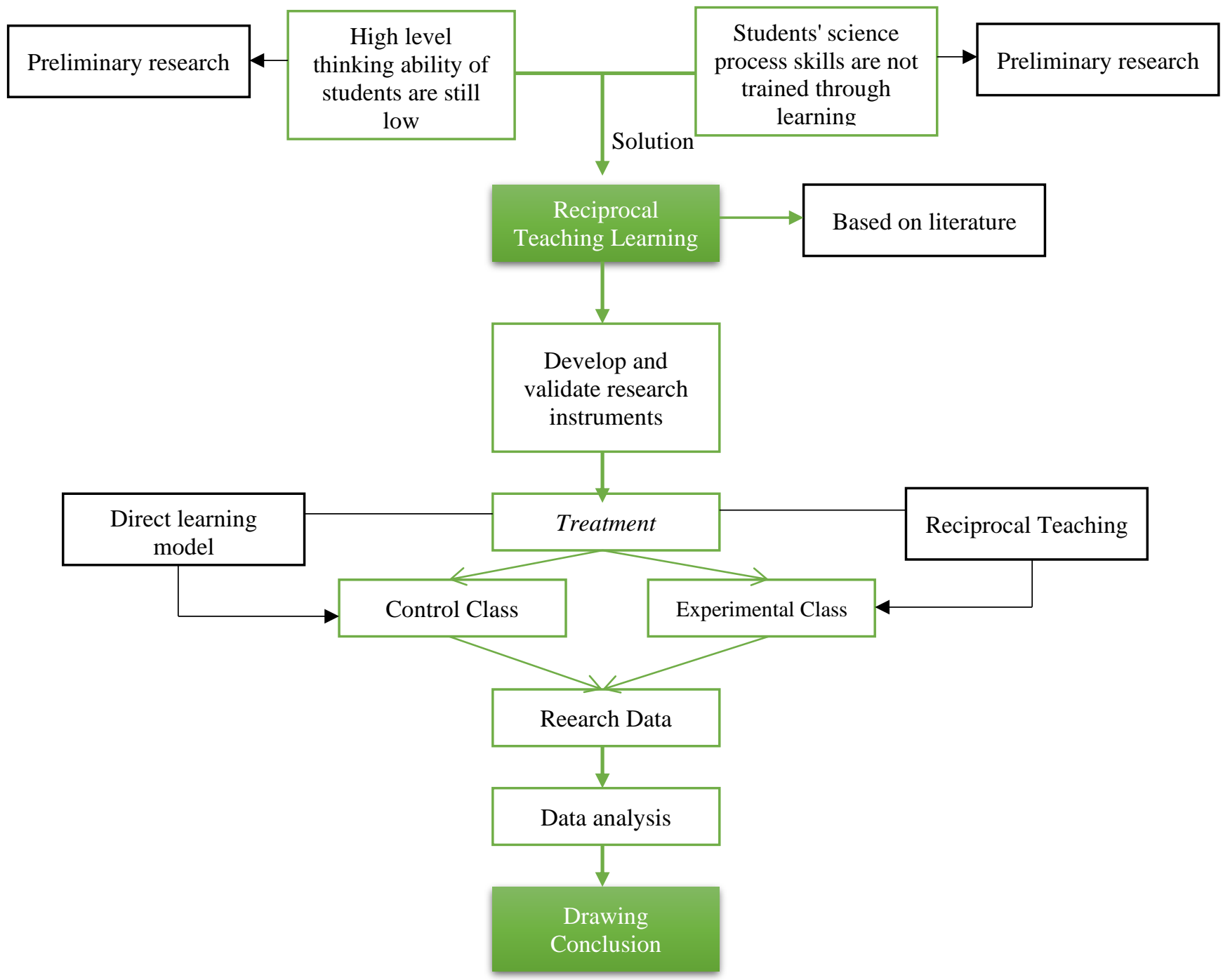

Figure 1. Research Framework

\section{RESULTS AND DISCUSSION}

\subsection{Higher-order thinking skiils}

Based on the research results, the average pretest and posttest scores for the control class and experimental class can be seen in Table 3 . 
Table 3. Description of Higher-Order Thinking Skills Data

\begin{tabular}{ccc}
\hline Class & Pretest average & Post-test average \\
\hline Control & 30,69 & 66,97 \\
Experimental & 31,54 & 77,71 \\
\hline
\end{tabular}

It can be seen that the pretest and posttest mean scores of the experimental class are higher than the control class. This also shows that the higher order thinking skills of experimental class students who use the reciprocal teaching model are higher than the other class.

\subsection{Science Process Skills}

Observations are made during the learning process and practicum. The observational data are presented in Table 4.

\begin{tabular}{ccccc}
\multicolumn{2}{c}{ Table 4 Results of the Observation Sheet of Science Process Skills Meeting I and II } \\
\cline { 2 - 3 } Class & I & II & & Category \\
& 66 & 79 & 73 & Good \\
Control & 69 & 83 & 76 & Good \\
Experiment & 69 & &
\end{tabular}

Based on the data in Table 4, it shows that the percentage value of the observation of science process skills in the control class and the experimental class increases at each meeting. These data are presented in Figure 2.

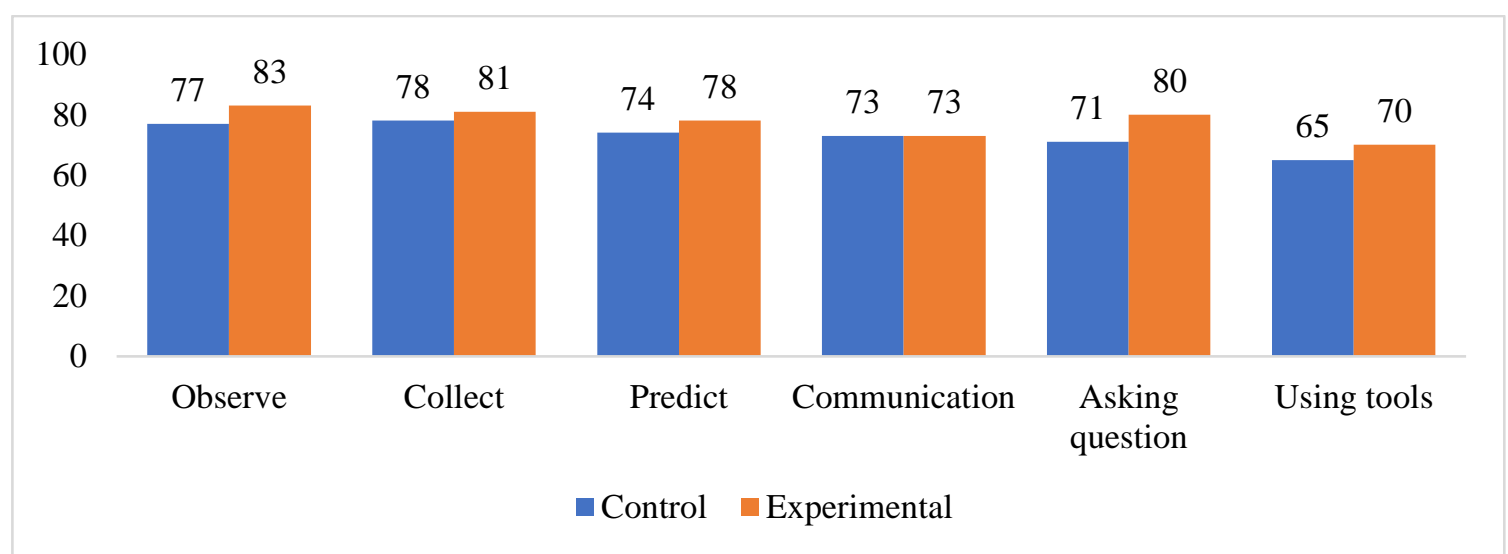

Figure 2. Science Process Skills in the Control Class and Experiment Class

Based on Figure 2, the observing indicator is an indicator that has very good criteria with a percentage value of $83.31 \%$. The indicator using the tool is the lowest aspect with a percentage value of $65.31 \%$. The results of all aspects of science process skills in the control class and the experimental class obtained an average presentation score of $73 \%$ and $76 \%$ respectively and based on the indicators of success, this value is categorized as good.

Before the data obtained is said to be correct, it is necessary to conduct prerequisite testing to determine whether the data is normally distributed and homogeneous, before being tested by the independent $t$ test. The normality test in this study used the Kolmogorov Smirnov test with a significant level of $\alpha=0,05 \mathrm{~d}$ with the SPSS 17 statistical application.The Kolmogorov Smirnov test results showed that the data were normally distributed as in Table 5. 
Table 5. Postest Normality Test Results

\begin{tabular}{|c|c|c|c|}
\hline \multirow{2}{*}{ Data } & \multicolumn{2}{|c|}{ Posttest } & \multirow{2}{*}{ Conclusion } \\
\hline & Control & Experimental & \\
\hline$(\mathrm{N})$ & 35 & 35 & $\mathrm{~L}_{\text {count }}<\mathrm{L}_{\text {table }}$ \\
\hline$\alpha$ & 0,05 & 0,05 & Data is normally \\
\hline Sig & 0,06 & 0,18 & distributed \\
\hline
\end{tabular}

The homogeneity test in this study was calculated using the homogeneity of variance test in the SPSS 17 program. This homogeneity test aims to determine whether the two samples have the same variant. The results of the posttest homogeneity showed that the data was homogeneous.

After the prerequisite test is carried out, namely the normality and homogeneity test, data that are normal and homogeneous can be tested with an independent sample t-test in the SPSS 17 statistical application. The data is obtained in Table 6.

Table 6. HOTS and SPS Hyposcription Tests

\begin{tabular}{ccccc}
\hline Data & \multicolumn{2}{c}{ HOTS } & T & sig \\
\cline { 2 - 5 } & $\mathbf{T}$ & sig & TPS \\
\hline $\mathrm{T}_{\text {count }}$ & 10,167 & 0,00 & 3,656 & 0,001 \\
$\mathrm{~T}_{\text {table }}$ & 1,996 & 0,05 & 1,996 & 0,05 \\
\hline
\end{tabular}

Based on Table $6, \mathrm{H}_{1}$ is accepted, meaning that the reciprocal teaching model has an effect on improving higher-order thinking skills and science process skills.

The effectiveness of a learning model or strategy can be measured using the effect size test. The effect size can be calculated using the formulation described by Hake [5-8]. The results of the posttest effect size test of high-order thinking skills are described in Table 7.

Table 7. Effect Size Test Result

\begin{tabular}{clcl}
\hline Class & SD & Effect Size & Criteria \\
\hline Control & 179,3 & 0,5 & moderate \\
Experiment & 18,47 & & \\
\hline
\end{tabular}

The results of the posttest effect size test high-order thinking skills obtained a value of $d=$ 0.5 , then these results are interpreted using the effect size table, it is found that the reciprocal teaching model affects high-order thinking skills by $69 \%$.

Learning in the control class sample (X MIA 1) used a conventional model (direct learning) following the teacher's previous teaching habits, and in the experimental class (X MIA 3) used the Reciprocal Teaching model. After the treatment was applied, there was a significant difference in the average posttest score, the control class got a score of 66.97 and the experimental class was 77.71. It can be seen that the posttest mean score of the experimental class is higher than the control class. This shows that the high-order thinking skills of students in the experimental class using the reciprocal teaching model are higher than the control class using conventional methods.

Observation of science process skills is carried out during the learning process and practicum using the observation sheet. In the experimental class, the SPS indicator with very good criteria was found in the observing and grouping indicators, while in the control class, all indicators received good criteria (one level lower than the results in the experimental class).

Reciprocal Teaching learning model trains students to learn independently, creatively, and actively in the learning process. The teacher only acts as a facilitator and provides opportunities for students to be directly involved during the learning process, so 
that students can develop process skills in the learning process. Reciprocal Teaching is a learning model in the form of peer tutoring activities (friends become tutors). In this learning model students act as "teachers" to convey learning topics to their friends. Meanwhile the teacher acts as a facilitator and mentor.

Hypothesis testing of the data from the SPS observation sheet in the experimental class and control class using the independent t-test shows the results of the calculation of the $t_{\text {count }}$ value that is greater than the $t_{\text {table }}(3.656>1.996)$ and the SPSS 17 test value, the sig $<0.05(0.001<0.05)$, then $\mathrm{H}_{1}$ is accepted, this shows that there is an effect of using the reciprocal teaching model on students' science process skills. This increase was also seen from the observation sheet of science process skills, that the percentage of students' SPS at each meeting increased in the experimental class that applied the reciprocal teaching model.

\section{CONCLUSION}

Based on the research results, it can be concluded that the reciprocal teaching model has an influence on the higher-order thinking skills and science process skills of students. The effectiveness of the reciprocal teaching model which is determined by the effect size test showed a result of 0.5 with moderate criteria, which means that the reciprocal teaching model has a moderate effect on higher-order thinking skills and science process skills with a percentage of $69 \%$.

\section{REFERENCES}

[1] D. Purtrianasari and W. Wasitohadi, "Pengaruh Penerapan Pendekatan Contextual Teaching and Learning (Ctl) Terhadap Hasil Belajar Matematika Ditinjau Dari Motivasi Belajar Siswa Kelas 5 Sd Negeri Cukil 01 Kecamatan Tengaran Kabupaten Semarang," Scholaria, vol. 5, no. 1, pp. 57-77, 2015.

[2] R. Yusuf, Sanusi, Maimun, E. Hayati, and I. Fajri, "Artikel Prosiding Seminar Nasional," in Prosiding Seminar Nasional: Reaktualisasi Konsep Kewarganegaraan Indonesia, 2019, pp. 185-200.

[3] W. Wahyu, R. Rusmansyah, and A. Sholahuddin, "Meningkatkan Kemampuan Berpikir Kreatif dan Self efficacy siswa menggunakan Model Creatuve Problem Solving Pada Materi Sistem Koloid," Jurnak Vidya Karya, vol. 32, no. 1, pp. 3644, 2017.

[4] K. C. Suryandari, S. Sajidan, S. B. Rahardjo, Z. K. Prasetyo, and S. Fatimah, "Project-based Science Learning and Pre-Service Teachers' Science Literacy Skill and Creative Thinking," Cakrawala Pendidik., vol. XXXVII, no. 3, pp. 345-355, 2018.

[5] A. Setyadi and A. A. Saefudin, "Pengembangan modul matematika dengan model pembelajaran berbasis masalah untuk siswa kelas VII SMP," Pythagoras J. Pendidik. Mat., vol. 14, no. 1, pp. 12-22, 2019, doi: 10.21831/pg.v14i1.16771.

[6] D. Putri, Sri Diana, Djamas, "Pengembangan Perangkat Pembelajaran Fisika Berbasis Keterampilan Berpikir Kritis dalam Problem-Based Learning," J. Ilm. Pendidik. Fis. Al-Biruni, vol. 6, no. 1, p. 125, 2017, doi: 10.24042/jpifalbiruni.v6i1.648.

[7] M. . Nur and A. Madkur, "Teachers' Voices on the 2013 Curriculum for English Instructional Activities," Int. J. English Educ., vol. 1, no. 2, pp. 119-134, 2014.

[8] L. Lutfianannisak and U. Sholihah, "Kemampuan Komunikasi Matematis Siswa dalam Menyelesaikan Soal Materi Komposisi Fungsi Ditinjau dari Kemampuan Matematika," J. Tadris Mat., vol. 1, no. 1, 2018, doi: 10.21274/jtm.2018.1.1.1-8. 
[9] A. H. Yanti, "Penerapan Model Problem Based Learning (PBL) terhadap Kemampuan Komunikasi dan Kemampuan Pemecahan Masalah Matematika Siswa Sekolah Menengah Pertama Lubuklinggau," J. Pendidik. Mat. Raflesia, vol. 2, no. 2, pp. 118-129, 2017.

[10] L. Suswati, L. Yuliati, and N. Mufti, "Pengaruh Integrative Learning Terhadap Kemampuan Berpikir Kritis dan Penguasaan Konsep Fisika Siswa Lis," J. Pendidik. sains, vol. 3, no. 2, pp. 49-57, 2015.

[11] Q. Fariyani, A. Rusilowati, and Sugianto, "Pengembangan Four-Tier Diagnostic Test Untuk Mengungkap Miskonsepsi Fisika Siswa SMA Kelas X," J. Innov. Sci. Educ., vol. 4, no. 2, pp. 41-49, 2015.

[12] E. Dewa, Maria Ursula Jawa Mukin, and Oktavina Pandango, "Pengaruh Pembelajaran Daring Berbantuan Laboratorium Virtual Terhadap Minat dan Hasil Belajar Kognitif Fisika," JARTIKA J. Ris. Teknol. dan Inov. Pendidik., vol. 3, no. 2, pp. 351-359, 2020, doi: 10.36765/jartika.v3i2.288.

[13] H. Aktamis and O. Ergin, "The Effect of Scientific Process Skills Education on Students' Scientific Creativity, Science Attitudes and Academic Achievements," AsiaPacific Forum Sci. Learn. Teach., vol. 9, no. 1, p. 21, 2008, [Online]. Available: http://search.proquest.com/docview/61875613?accountid=14719.

[14] H. El-Senousy and J. Alquda, "The Effect of Flipped Classroom strategy using Blackboard Mashup tools in enhancing achievement and Self- Regulated learning skills of university students," World J. Educ. Technol. Curr. Issues, vol. 6, no. 3, p. 144, 2017, doi: 10.18844/wjet.v6i3.1974.

[15] N. Mustaffa, Z. Ismail, Z. Tasir, and M. N. H. M. Said, "The Impacts of Implementing Problem-Based Learning (PBL) in Mathematics: A Review of Literature," Int. J. Acad. Res. Bus. Soc. Sci., vol. 6, no. 12, 2016, doi: 10.6007/ijarbss/v6-i12/2513.

[16] H. S. Ramadhani, "Efektivitas Metode Pembelajaran SCL (Student Centered Learning) dan TCL (Teacher Centered Learning) pada Motivasi Instrinsik \& Ekstrinsik Mahasiswa Psikologi UNTAG Surabaya Angkatan Tahun 2014-2015," Pers. J. Psikol. Indones., vol. 6, no. 2, pp. 66-74, 2017.

[17] M. Syukri, H. Lilia, and M. M. T. Subahan, "Pendidikan STEM dalam Entrepreneurial Science Thinking 'ESciT': Satu Perkongsian Pengalaman dari UKM untuk Aceh," Aceh Dev. Int. Conf., no. 26-28 MARCH, pp. 105-112, 2013.

[18] Uslan dan Nuriyah, "Model Student Centered Learning (SCL) di Sekolah Dasar (SD) Yang Inovatif Terintegrasi Pembelajaran Terpadu," J. Pendas Mahakam, vol. 3, no. 1, pp. 63-67, 2018.

[19] D. Effendi and A. Wahidy, "Pengembangan Kreativitas Inovatif melalui Pembelajaran Digital," in Prosiding Seminar Nasional Pendidikan Program Pascasarjana Universitas PGRI Palembang, 2020, vol. 2, pp. 999-1015.

[20] M. Fathurrohman, Model-model Pembelajaran Inovatif: Alternatif Desain Pembelajaran yang Menyenangkan. Yogyakarta: Ar-Ruzz Media, 2015.

[21] A. Shoimin, 68 Model Pembelajaran Inovatif dalam Kurikulim 2013. Yogyakarta: Ar-Ruzz Media, 2017.

[22] Z. Aqib, Model-Model,Media Dan Strategi Pembelajaran Kontekstual (Inovatif). Bandung: CV Yrama Widya, 2014.

[23] U. A.F, Masrukan, and A. R, "Meningkatkan Kemampuan Berpikir Kreatif Siswa Melalui Pembelajaran Model Taba Berbantuan Geometer's Sketchpad," Kreano J. Mat. Kreat., vol. 5, no. 1, pp. 63-72, 2014, doi: 10.15294/kreano.v5i1.3279.

[24] M. Okkinga, R. van Steensel, A. J. S. van Gelderen, and P. J. C. Sleegers, "Effects 
of reciprocal teaching on reading comprehension of low-achieving adolescents. The importance of specific teacher skills," J. Res. Read., vol. 41, no. 1, pp. 20-41, 2018, doi: 10.1111/1467-9817.12082.

[25] A. Zendler and S. Reile, "The effect of reciprocal teaching and programmed instruction on learning outcome in computer science education," Stud. Educ. Eval., vol. 58, no. December 2017, pp. 132-144, 2018, doi: 10.1016/j.stueduc.2018.05.008.

[26] T. Andira, B. Santoso, and M. Yusup, "Penerapan model pembelajaran reciprocal teaching ditinjau dari kemampuan penalaran matematis peserta didik pada materi bangun datar segiempat Applying of reciprocal teaching learning model viewed from students ' mathematical reasoning on quadrilateral mat," Pythagoras, vol. 13, no. 1, pp. 88-98, 2018.

[27] D. Mulyono, M. Asmawi, and T. Nuriah, "The Effect of Reciprocal Teaching, Student Facilitator and Explaining and Learning Independence on Mathematical Learning Results by Controlling the Initial Ability of Students," Int. Electron. J. Math. Educ., vol. 13, no. 3, pp. 199-205, 2018, doi: 10.12973/iejme/3838.

[28] T. T. Wu and A. C. Chen, "Combining e-books with mind mapping in a reciprocal teaching strategy for a classical Chinese course," Comput. Educ., vol. 116, pp. 6480, 2018, doi: 10.1016/j.compedu.2017.08.012. 